International Research Journal of Management, IT \& Social Sciences
Available online at https://sloap.org/journals/index.php/irjmis/
Vol. 6 No. 5, September 2019, pages: 218 225
ISSN: 2395-7492
https://doi.org/10.21744/irjmis.v6n5.731

\title{
Analysis of Impact Factors on Farmers Income
}

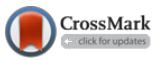

I Putu Irvan ${ }^{a}$

Ni Nyoman Yuliarmi ${ }^{\text {b }}$

\section{Article history:}

Received: 09 March 2019

Accepted: 31 July 2019

Published: 04 September 2019

\section{Keywords:}

income;

labor;

land area;

production costs;

production;

\begin{abstract}
The role of the Agriculture Sector is very important in the economy of most developing countries. Increasing agricultural productivity is a priority for achieving sustainable yield improvements and improving agricultural technology and management, improving groundwater and post-harvest management. Bali Province is a province that has potential in the agricultural sector. Various policies have been made by the government in increasing agricultural production such as irrigation development, production input subsidies, farm credit, and institutional development. The large role of agriculture in the GRDP should indicate the level of welfare of farmers. The research objectives are 1) analyzing the effect of labor, land area, production costs, and cultivation techniques on production, 2) analyzing the effect of labor, land area, production costs, cultivation techniques, and the amount of production on income, 3) analyzing technology as a variable moderating between labor towards production, 4) analyzing technology moderating between labor variables on income. The study was conducted in Jatiluwih Village, Penebel District, Tabanan Regency with a sample of 135 people from 400 rice farmers in Jatiluwih Village. The analytical method used is path analysis. Based on the analysis, it can be concluded that the workforce, land area, production costs, and cultivation techniques have a direct effect on production, workforce, land area, production costs, and cultivation techniques.
\end{abstract}

\section{Author correspondence:}

I Putu Irvan,

Faculty of Economics and Business,

Udayana University, Denpasar, Indonesia.

Email address: irvan_iputu@yahoo.co.id

\footnotetext{
a Udayana University, Denpasar, Indonesia

${ }^{\mathrm{b}}$ Udayana University, Denpasar, Indonesia
} 


\section{Introduction}

The agriculture sector is a very important sector in the economy of most developing countries as one of the economic sectors which are a source of income for workers with an estimated 60 to 70 percent in developing countries (Nguyen et al., 2015). Agricultural development needs to receive better attention, even though the priority on industrialization policies has been dropped, the agricultural sector can have the ability to generate increased income (Sudarman, 2001; Muliarta, 2016). One of the role of the agricultural sector as meeting basic needs or food, the increasing population will automatically make food consumption will also increase so as to improve the economy for farmers. The agricultural sector is generally a sector that can be captured for investment (Winters et al., 1998). Increasing agricultural productivity must be a priority for achieving sustainable yield improvements and involving improving agricultural technology and management including improving groundwater and post-harvest management (Al-Haboby et al., 2016). Such conditions indicate that the agricultural sector should be used as an economic sector which is parallel with other sectors. This sector no longer only acts as a supporting actor let alone extras for national development but must become the main actor in line with the industrial sector. It cannot be denied, the success of the industrial sector is highly dependent on the development of the agricultural sector which can be the basis of economic growth.

Bali Province as one of the provinces in Indonesia which is famous for its natural beauty and culture, and has considerable potential in the agricultural sector. Most Balinese people still depend on their lives in the agricultural sector, even from the culture of the agricultural community in Bali has given birth to an organization in the field of agriculture called subak. The agricultural sector in Bali also contributed significantly to economic growth in the Province of Bali. Economic development in the era of regional autonomy faces various challenges, both from internal and external factors. The problem of inequality and globalization issues have implications for accelerating regional economic development in a focused manner through the development of regions and its flagship products. The current regional development paradigm needs to pay attention to regional specificity which can increase the potential of the region. Regional economic development efforts have the main objective to increase the number and types of job opportunities by utilizing available resources (Herdhiansyah et al., 2012; Sadguna et al., 2017).

The agricultural sector in Bali is the second largest contributor to regional income after tourism (trade, hotels, and restaurants). Based on data from the Central Statistics Agency (BPS) of the Province of Bali (2016), in 2017 the agricultural sector has a large contribution to the Gross Regional Domestic Product (GRDP) of the Province of Bali, which is 16.82 percent of the tourism sector by 29.89 percent, and the rest contributed by other sectors. Therefore, the agriculture sector should get priority because it contributes to the GRDP.

Various policies have been carried out by the government in increasing agricultural production such as irrigation development, subsidized production inputs (seeds, fertilizers, and pesticides), farm credit, and institutional development of farming (Bank Indonesia, 2008 in Advisory, 2014). the future seems to be increasing, which is projected that in 2015 rice needs will be 653,270 tons, 2020 will be 698,010 tons, and in 2025 will be 738,653 tons, assuming: the average harvest area is 147,510 ha; rice productivity level of 5.6 tons/ha with productivity growth of 0.38 percent; conversion value of rice to rice 0.63 percent; rice consumption averaged $112.95 \mathrm{~kg}$ per capita per year; and an average population growth rate of 2.15 percent (Distan Bali Province, 2012). The amount of rice production in the Regency/City in the Province of Bali.

Jatiluwih Village has an organized irrigation management system and this system is a cultural heritage that has been applied for a long time. Through this system, the government distributes fertilizer subsidies to farmers in the field. According to Asnawi (2014), national rice production tends to decrease along with the deterioration and decrease in soil fertility due to continuous intensification. Given the problems that arise from the lack of productivity levels in the agricultural sector, farmers should start to be serious in dealing with this with various factors that affect productivity. From the farmer side, productivity is an important factor in realizing the success of increasing the income of farmers themselves, but it can also produce farm products that are free of chemicals whose impacts are natural and environmental damage (Widnyana, 2011; Maydasari, 2016).

Sulaeman et al., (2014), states that productivity also reflects the work ethic of farmers both mentally and others. Thus the farmers who jump directly try to improve their performance with a variety of policies that are efficient, able to increase productivity. In addition, there are many factors that lead to a decline in the agricultural sector as seen from productivity. In the case of the decline in the agricultural sector triggered by productivity, the cause is uncertain climate which is the reason for farmers to decrease productivity, but also the declining water debit is also an obstacle in the ongoing agricultural process. Kieso et al., (2011), State that income is gross inflows from the economic benefits arising from activities over a period and the inflows will result in an increase in equity but not from investment contributions.

Irvan, I. P., \& Yuliarmi, N. N. (2019). Analysis of impact factors on farmers income. International Research Journal of Management, IT and Social Sciences, 6(5), 218-225. https://doi.org/10.21744/irjmis.v6n5.731 
Revenue has many names such as sales, fees, interests, dividends, and royalties. Net income from farming is the difference between gross income (revenue) of farming and total expenditure of farming. While the gross income of farming is defined as the total production value of farming in a certain period of time both for sale and not for sale (Soekartawi et al., 2002; Widarma \& Setiawina, 2019).

\section{Literature Review and Hypothesis}

The cost of agricultural production facilities is the sum of the costs of seeds, fertilizer costs, and the cost of pesticides. Labor costs outside the family are costs used to pay wages for workers outside the family. The greater the production costs incurred by rice farmers in the supply of certain factors of production will affect the results of production where if there is no equal distribution of the factors of production will lead to production not optimal or efficient. Due to inefficient production will cause farmers' income will decrease. Here, if the use of production costs gets higher, the income of rice farmers will decrease otherwise, if the use of production costs is small, the income of rice farmers will increase.

Labor is the most important factor in production. The amount of labor that is increasingly lacking must be balanced with the development of technology. In this research, technology cannot mediate between labor and production variables. This is because the presence of machines with sophisticated technology has not been able to increase the production of farmed rice. The development of pest technology that attacks rice is also increasing and the existence of technology that is increasingly developing can reduce the use of human labor in the village of Jatiluwih in fewer numbers due to the younger generation most are reluctant to work on land. The results of this study are in line with the research of Indrawati (2012), wherein her research the more advanced technology will cause the use of fewer human labor so that the shortage of labor can be fulfilled by the presence of machines with production results which of course also increase.

H1: Labor, land area, production costs, and cultivation techniques have a positive and significant effect directly on farmers' production in Jatiluwih Village, Penebel District, Tabanan Regency.

Variable production costs have a positive and significant effect on the income of rice farmers in Jatiluwih Village. This shows a direct relationship between production costs with the income of rice farmers in Jatiluwih Village so that the decrease in production costs will increase the income of rice farmers in Jatiluwih Village. This is reinforced by the results of research conducted by Zaini (2010), that the production costs issued a significant effect on the income of rice farmers in Loa Gagak, Kutai Kartanegara Regency.

Production costs incurred by farmers, one of which is in the supply of fertilizers, greatly affects the yield of production which also ultimately affects the income of farmers. To reduce costs in the factor of fertilizer production, the government adopted a policy of providing subsidies to farmers in terms of providing production factors in the form of fertilizer so as to reduce production costs. The fewer production costs incurred by farmers can be diverted to other factors of production that are needed. Therefore, fertilizer subsidies provided by the government can reduce the production costs of farmers so that income can increase and vice versa.

The wider land area causes greater production costs incurred by farmers. In this case, there is a positive effect where a large area of land requires a large number of factors of production that are increasing so that it is necessary to have the policy to reduce the cost of production. Farmers working on large areas of land generally produce a lot of rice production, so that the results of these products can be sold by farmers who can increase income.

H2: Labor, land area, production costs, cultivation techniques, and the amount of production have a positive and significant effect directly on farmers' income in Jatiluwih Village, Penebel District, Tabanan Regency

In producing rice, farmers use many factors of production as their input. The most frequently used production factors are land, fertilizer, bait, pesticides, labor, and technology. Agriculture in Bali, in general, has its own uniqueness where there is a religious element that is included in it which certainly adds to the cost of production. The role of the agricultural sector in economic development is very important because most members of society in poor countries depend their lives on the sector. If planners really pay attention to the welfare of their people, then the only way is to improve the welfare of most members of their community who live in the agricultural sector.

Agriculture will maximize production by using available inputs. By maximizing this production, the profit value that will be obtained is also higher. Here the results of production are largely determined by the factors that influence it. One factor in the production of food crops such as rice is the availability of sufficient land. However, at present in 
Tabanan District many agricultural lands have been shifted to non-agricultural sectors, causing the production process to be disrupted.

The land is a physical environment that includes climate, soil relief, hydrology and plants which to a certain extent will affect the ability of land use (Kartika, 2011; Sugiana et al., 2018). According to Arsyad (2002), the land is part of a landscape that includes an understanding of the physical environment including climate, topography/relief, hydrology and even the state of natural vegetation, all of which will potentially affect various human activities both past and present. The more extensive land used in production is of course also the higher income generated or vice versa if the area of land used is small, the income earned by rice farmers will also be low. Therefore the area of land is very influential on the income of farmers if the area of land cultivated is narrow then the income of farmers is small or vice versa. So, the relationship between land area and rice farmers' income has a positive relationship. The cost of production of rice farming is the sum of the cost of labor outside the family with the cost of agricultural production facilities.

H3: Technology moderates the effect of labor on farmers production in Jatiluwih Village, Penebel District, Tabanan Regency

H4: Technology moderates the effect of labor on farmers' income in Jatiluwih Village, Penebel District, Tabanan Regency

\section{Materials and Methods}

The location of the study was conducted in Jatiluwih Village, Penebel District, Tabanan Regency, Bali Province with various considerations, namely: (1) Agriculture (paddy fields) in Jatiluwih Village, Penebel Subdistrict namely Jatiluwih subak can be considered to represent highland agricultural land in Tabanan Regency, (2) Jatiluwih Village is also a cultural heritage, (3) At this location land conversion has not yet occurred from agriculture (rice fields) to nonagriculture, (4) irrigation water resources available throughout the season. There are also several other reasons, namely the absence of research on agriculture in Jatiluwih and also information on how and how much influence the labor force, land area, production costs, cultivation techniques, technology in Jatiluwih Village, Penebel District, Tabanan Regency.

The population in this study were all rice farmers in Jatiluwih Village. The number of farmers in Jatiluwih Village is 400 people. The number of sample members taken or the minimum sample size will be determined using the Slovin approach. According to these calculations, the farmers who were sampled based on the strata of the land area were ninety-eight (98) smallholder farmers, twenty-eight (28) medium cultivators, and nine (9) farmers with large arable land areas. Furthermore, the process of selecting samples in each stratum of the land area will be chosen randomly. The analytical method used in this study is path analysis.

The independent variables of this study are labor, land area, production costs, and cultivation techniques, the mediating variable in this study is production, the moderating variable in this study is technology, and the dependent variable of this study is the income of rice farmers in Jatiluwih Village, District Penebel, Tabanan Regency.

\section{Results and Discussions}

This study includes four variables consisting of four independent variables, one mediating variable, one moderation variable, and one dependent variable. The independent variables of this study are labor, land area, production costs, and cultivation techniques, the mediating variable in this study is production, the moderating variable in this study is technology, and the dependent variable of this study is the income of rice farmers in Jatiluwih Village, District Penebel, Tabanan Regency. The results of the processed data in the study are as follows:

Table 1

Sub structural I of the regression coefficient

\begin{tabular}{ccclcr}
\hline Model & & $\begin{array}{c}\text { Unstandardized } \\
\text { Coefficients } \\
\text { Std. Error }\end{array}$ & $\begin{array}{l}\text { Standardized } \\
\text { Coefficients } \\
\text { Beta }\end{array}$ & T & Sig. \\
\hline 1 (Constant) & $-8,799$ & 1,725 & & $-5,102$ &, 000 \\
\hline
\end{tabular}

Irvan, I. P., \& Yuliarmi, N. N. (2019). Analysis of impact factors on farmers income. International Research Journal of Management, IT and Social Sciences, 6(5), 218-225. https://doi.org/10.21744/irjmis.v6n5.731 


\begin{tabular}{llllll}
\hline LnX1 &, 446 &, 092 &, 239 & 4,838 &, 000 \\
LnX2 &, 290 &, 070 &, 222 & 4,142 &, 000 \\
LnX3 &, 720 &, 135 &, 231 & 5,325 &, 000 \\
X4 &, 555 &, 082 &, 239 & 6,758 &, 000 \\
X5 &, 250 &, 104 &, 134 & 2,409 &, 017 \\
X1_X5 &, 023 &, 015 &, 110 & 1,493 &, 138 \\
\hline
\end{tabular}

Information:

$\mathrm{X} 1$ = Labor

$\mathrm{X} 2=$ Land area

X3 = Production Costs

$\mathrm{X} 4=$ Cultivation Technique

$\mathrm{X} 5=$ Technology

$\mathrm{Y} 1=$ Production

Based on Table 1 it can be explained that the variable of labor (X1) has a positive and significant effect on production (Y1), where if there is an increase in the amount of labor used to eat coupled with an increase in production of 0.446 kilograms or vice versa. Land area variable (X2) has a positive and significant relationship to production (Y1), where if the area of land used is increasing or getting wider the amount of production will increase by 0.290 are or vice versa. Variable production costs (X3) have a positive and significant effect on production (Y1) which means that if the production costs used to rise, there will be an increase in production by 0.720 or vice versa. The use of cultivation techniques (X4) greatly affects production (Y1) directly and significantly, when the application of non-organic cultivation techniques is applied, the product produced is more than 0.555 . The results of this study are in accordance with the H1 hypothesis: Labor, land area, production costs, and cultivation techniques have a positive and significant effect directly on farmers' production in Jatiluwih Village, Penebel District, Tabanan Regency. The results of this study are in line with the research of Indrawati (2012), wherein his research the more advanced technology will cause the use of human resources which is getting less so that the shortage of labor can be filled with the presence of machines with production results which of course also increase.

Technology as a mediating variable between labor (X1) and production (Y1) has no effect. If technology is used and labor that is used is still not certain amount can increase production from rice farmers seen from a significant level of $0.138>0.05$. The results of this study reject $\mathrm{H} 3$ : Technology moderates the effect of labor on farmers' production in Jatiluwih Village, Penebel District, Tabanan Regency.

Table 2

Sub structural II of the regression coffecient

\begin{tabular}{|c|c|c|c|c|c|c|}
\hline \multirow{2}{*}{\multicolumn{2}{|c|}{ Model }} & \multicolumn{2}{|c|}{$\begin{array}{l}\text { Unstandardized } \\
\text { Coefficients }\end{array}$} & \multirow{2}{*}{$\begin{array}{l}\text { Standardized } \\
\text { Coefficients } \\
\text { Beta }\end{array}$} & \multirow[t]{2}{*}{$\mathrm{T}$} & \multirow[t]{2}{*}{ Sig. } \\
\hline & & B & Std. Error & & & \\
\hline \multirow[t]{8}{*}{1} & (Constant) & 11,986 & ,500 & & 23,967 & 000 \\
\hline & LnX1 & ,115 & ,027 & ,055 & 4,342 & ,000 \\
\hline & LnX2 & ,022 & ,020 & ,015 & 1,094 & ,276 \\
\hline & LnX3 & ,025 & ,039 & ,007 & ,629 &, 531 \\
\hline & $\mathrm{X} 4$ & ,086 & ,025 & ,033 & 3,416 & ,001 \\
\hline & X5 & ,061 & ,028 & ,029 & 2,193 & ,030 \\
\hline & X1_X5 &,- 015 & ,004 &,- 066 & $-3,756$ & ,000 \\
\hline & LnY1 & 1,055 & ,023 & ,945 & 45,152 &, 000 \\
\hline
\end{tabular}

Primary Data, 2019

Information :

$\mathrm{X} 1$ = Labor

$\mathrm{X} 2=$ Land area

$\mathrm{X} 3=$ Production Costs

$\mathrm{X} 4=$ Cultivation Techniques 
$\mathrm{X} 5=$ Technology

$\mathrm{Y} 1=$ Production

$\mathrm{Y} 2=$ Income

Based on Table 2 it can be explained that the variable of labor (X1) has a significant and positive effect on income (Y2), where if there is an increase in the number of workers used to eat coupled with an increase in income of 0.115 thousand rupiahs or vice versa. Land area variable (X2) has a positive but not significant relationship to income (Y2), where land area has no influence on income as seen from the significance level of $0.276>0.05$. Production cost variable (X3) has a positive but not significant relationship to income (Y2) which means that land area has no influence on income as seen from the significance level of $0.531>0.05$. The use of cultivation techniques (X4) directly influences income (Y2) and significantly, when the application of non-organic cultivation techniques is applied, the income generated is more than 0.86 thousand rupiahs. The use of production (Y1) greatly influences income (Y2) positively and significantly, where if there is an increase in production by one unit it will be followed by an increase in income of 1,055 thousand rupiahs or vice versa. Labor variable (X1) and technology (X5) significant effect on income (Y2). The results of this study are in accordance with $\mathrm{H} 2$ : Labor, land area, production costs, cultivation techniques, and total production have a positive and significant effect directly on farmers' income in Jatiluwih Village, Penebel District, Tabanan Regency

The effect of technology as a mediating variable between labor (X1) and income (Y2) has a negative and significant effect, if the technology is used and the labor force used is still the same or constant amount will be able to reduce the income of rice farmers by -0.015 thousand rupiah or vice versa. The results of this study reject H4: Technology moderates the effect of labor on farmer's income in Jatiluwih Village, Penebel District, Tabanan Regency.

Value of Standard Error of Estimate

To find out the value of e1 which shows the number of variances in the variable production costs that are not explained by the fertilizer subsidy variable and the land area can be calculated using the formula:

$$
\begin{aligned}
\boldsymbol{e}_{1} & =\sqrt{\mathbf{1}-\boldsymbol{R} \boldsymbol{i}^{2}} \\
& =\sqrt{\mathbf{1 - 0 , 9 5 2}} \\
& =0,048
\end{aligned}
$$

Meanwhile, to find out the e2 value which shows the variance of farmer income variables that are not explained by the fertilizer subsidy variable, land area, and production costs, it can be calculated using the formula:

$$
\begin{aligned}
\boldsymbol{e}_{2} & =\sqrt{1-\boldsymbol{R} \dot{\boldsymbol{i}}^{2}} \\
& =\sqrt{1-0,997} \\
& =0,003
\end{aligned}
$$

\section{Model Validity Check}

To check the validity of the model, there are indicators to carry out an examination that is the coefficient of determination of the total results as follows:

(1) The results of the total determination coefficient

$\mathrm{R}^{2} \mathrm{~m}=1-(\mathrm{e} 1)^{2}(\mathrm{e} 2)^{2}$

$\mathrm{R}^{2} \mathrm{~m}=1-(0.048)^{2}(0.003)^{2}$

$\mathrm{R}^{2} \mathrm{~m}=0.99$

Information :

$\mathrm{R}^{2} \mathrm{~m}$ : The coefficient of total determination

e1.e2: The standard estimated error value

Based on the calculation of the total determination coefficient, it is obtained that the diversity of data that can be explained by the model is 99 percent or in other words the information contained in the data by 99 percent can be explained by the model, while the remaining 1 percent is explained by other variables not contained in model.

Irvan, I. P., \& Yuliarmi, N. N. (2019). Analysis of impact factors on farmers income. International Research Journal of Management, IT and Social Sciences, 6(5), 218-225. https://doi.org/10.21744/irjmis.v6n5.731 
Testing mediation variables can also be done with a procedure developed by Sobel (1982), known as the Sobel test (Sobel Test). This Sobel test was carried out by testing the strength of the indirect effect of the independent variables $\mathrm{X} 1, \mathrm{X} 2, \mathrm{X} 3, \mathrm{X} 4$, on the dependent variable Y2 through the intervening variable Y1 (Suyana Utama, 2016; Arnawa et al., 2017). Table 5.27 presents the nonstandard and standard error coefficients of the independent variables X1, X2, $\mathrm{X} 3$, and $\mathrm{X} 4$, towards the mediation variable $\mathrm{Y} 1$, as well as the nonstandard coefficient and standard error of the mediating variable $\mathrm{Y} 1$ to the dependent variable $\mathrm{Y} 2$, which will then be used in the calculation Sobel test.

Based on the Sobel test, the value of $\mathrm{z}=4.80943>\mathrm{z}$ table $(0.05)=(1.96)$ which means that the production variable (Y1) fully mediates the effect of the labor variable (X1) on the income variable. Based on the Sobel test, the value of $\mathrm{z}=4.12372>\mathrm{z}$ table $(0.05)=(1.96)$ which means that the production variable $(\mathrm{Y} 1)$ fully mediates the effect of the land area variable $(\mathrm{X} 2)$ on the income variable. Based on the Sobel test, the value of $\mathrm{z}=5.28670>\mathrm{z}$ table $(0.05)=1.96$ which means that the production variable (Y1) fully mediates the effect of the production cost variable (X3) on the income variable. Based on the Sobel test, the value of $\mathrm{z}=6.68237>\mathrm{z}$ table $(0.05)=1.96$ which means that the production variable (Y1) partially mediates the influence of the cultivation technique variable (X4) on the Income (Y2)

Based on the Sobel test results above, it can be concluded that the Production variable (Y1) mediates the influence of the Labor variable (X1), Land area (X2), production cost variable (X3) and cultivation technique variable (X4) on the Income variable (Y2) ) rice farmers in Jatiluwih Village, Penebel District, Tabanan Regency.

\section{Conclusion}

Labor, land area, production costs, and cultivation techniques directly influence production. Labor, land area, production costs, and cultivation techniques affect the income of farmers through production. Technology as a moderating variable for labor and production. Researchers suggest to rice farmers to be able to utilize the agricultural land they have in order to get optimal results. For example by maintaining the fertility of existing land. Rice farmers in Jatiluwih Village, Penebel District, Tabanan Regency in order to maintain their productivity by utilizing all the factors of production they have more intensively and pay more attention to achieving the desired target so as to increase the income of the farmers themselves. The Regional Government, in general, the Agriculture Office in Tabanan Regency and especially the Penebel District Technical Implementation Unit can provide and be able to provide infrastructure for farmers in the area. For example, by supervising the distribution of fertilizer subsidies to suit the allotment and area of land owned by the farmer, thereby reducing fraud and appropriate fertilizer subsidies. In addition, the government also needs to conduct socialization and supervision of farmers regarding land management and cultivation techniques which are certainly more organic so that soil fertility is maintained, forming farmer groups in order to maintain the sale value of crops so that they are not bought cheaply, as well as educating the public about World Cultural Heritage in order to remain sustainable.

\section{Conflict of interest statement}

The authors declared that they have no competing interest.

\section{Statement of authorship}

The authors have a responsibility for the conception and design of the study. The authors have approved the final article.

\section{Acknowledgments}

The authors would like to thank the editor of IRJMIS for their valuable time, support, and advice in completing the present research. 


\section{References}

Al-Haboby, A., Breisinger, C., Debowicz, D., El-Hakim, A. H., Ferguson, J., Telleria, R., \& Van Rheenen, T. (2016). The role of agriculture for economic development and gender in Iraq: a computable general equilibrium model approach. The Journal of Developing Areas, 50(2), 431-451.

Arnawa, I. K., Sukerta, I. M., Martiningsih, N. G. A. E., \& Astuti, P. S. (2017). Minapolitan area development strategy: an effort to increase fisherman income, Gianyar regency, Bali Indonesia. International Journal of Life Sciences, 1(2), 39-47. https://doi.org/10.21744/ijls.v1i2.40

Arsyad, A. (2002). Media pembelajaran, edisi 1. Jakarta: PT. Raja Grafindo Persada, 36.

Asnawi, R. (2014). Analisis fungsi produksi usahatani ubikayu dan industri tepung tapioka rakyat di Provinsi Lampung.

Herdhiansyah, D., Sutiarso, L., Purwadi, D., \& Taryono, T. (2012). Strategi pengembangan potensi wilayah agroindustri perkebunan unggulan. Jurnal Teknik Industri, 13(2), 201-209. https://doi.org/10.22219/JTIUMM.Vol13.No2.201-209

Indrawati, N. (2012). Analisis faktor-faktor yang mempengaruhi underpricing pada penawaran umum perdana. Jurnal Akuntansi dan Bisnis, 5(1).

Kartika, A. (2011). Faktor-faktor yang mempengaruhi audit delay pada perusahaan manufaktur yang terdaftar di BEI. Dinamika Keuangan dan Perbankan, 3(2), 152-171.

Kieso, D. E., Weygandt, J. J., \& Warfield, T. D. (2011). Intermediate Accounting, Working Papers (Vol. 2). John Wiley \& Sons.

Maydasari, E. (2016). The analyses of factors influencing farmer motivation at cacao farming in North Lombok. International Research Journal of Engineering, IT \& Scientific Research, 2(9), 18-25.

Muliarta, I. N. (2016). The evaluation of implementation of integrated farming system program and the reality of increasing farmers income in Bali. International Research Journal of Engineering, IT \& Scientific Research, 2(7), 108-114.

Nguyen, A. T., Dzator, J., \& Nadolny, A. (2015). Does contract farming improve productivity and income of farmers?: A review of theory and evidence. The Journal of Developing Areas, 49(6), 531-538. https://doi.org/10.1353/jda.2015.0094

Sadguna, D. N., Sulistiawati, N. P. A., \& Astiari, N. K. A. (2017). Contributions of household income of farmers as palm crafts outside agriculture sector. International Research Journal of Engineering, IT \& Scientific Research, 3(5), 86-96.

Sobel, M. E. (1982). Asymptotic confidence intervals for indirect effects in structural equation models. Sociological methodology, 13, 290-312.

Soekartawi, A. S., Dillon, J. L., \& Hardaker, J. B. (2002). Prinsip dasar ekonomi pertanian. Rajagrafindo Persada, Jakarta.

Sudarman, A. Algifari. 2001. Ekonomi Mikro-Makro. BPFE. Yogyakarta.

Sugiana, I. G. N., Sadguna, D. N., Tonga, Y., \& Kaca, I. N. (2018). The study on farmers welfare. International Journal of Life Sciences, 2(1), 29-41. https://doi.org/10.29332/ijls.v2n1.92

Sulaeman, S., Benidris, M., \& Mitra, J. (2014, September). A method to model the output power of wind farms in composite system reliability assessment. In 2014 North American Power Symposium (NAPS) (pp. 1-6). IEEE. https://doi.org/10.1109/NAPS.2014.6965475

Utama, S. Made. 2008. Aplikasi Analisis Kuantitatif.

Widarma, G., \& Setiawina, N. D. (2019). Factors of influencing household production and welfare of corn farmers. International Research Journal of Management, IT and Social Sciences, 6(1), 103-112. https://doi.org/10.21744/irjmis.v6n1.599

Widnyana, I. K. (2011). Upaya Meningkatkan Pendapatan Petani Melalui Pendampingan Penerapan Ipteks Peningkatan Produktivitas Padi Berbasis Organik (P3BO). Jurnal Ngayah, 2(2).

Winters, P., De Janvry, A., Sadoulet, E., \& Stamoulis, K. (1998). The role of agriculture in economic development: visible and invisible surplus transfers. The Journal of Development Studies, 34(5), 71-97. https://doi.org/10.1080/00220389808422537

Zaini, A. (2010). Analisis Tingkat Pencapaian Swasembada Beras di Kalimantan Timur. SOCA: Jurnal Sosial, Ekonomi Pertanian, 162-168.

Irvan, I. P., \& Yuliarmi, N. N. (2019). Analysis of impact factors on farmers income. International Research Journal of Management, IT and Social Sciences, 6(5), 218-225. https://doi.org/10.21744/irjmis.v6n5.731 